\title{
Two new species of the tropical facelinid nudibranch Moridilla Bergh, 1888 (Heterobranchia: Aeolidida) from Australasia
}

\author{
Leila Carmona ${ }^{1, *}$ and Nerida G. Wilson ${ }^{2}$ \\ 1 Department of Marine Sciences, University of Gothenburg, Box 460, Gothenburg 40530, Sweden; \\ Gothenburg Global Biodiversity Centre, Box 461, Gothenburg SE-405 30, Sweden. \\ ${ }^{2}$ Molecular Systematics Unit, Western Australian Museum, Locked Bag 49, Welshpool DC, Western \\ Australia 6986, Australia; School of Biological Sciences, University of Western Australia, Crawley, \\ Western Australia 6009, Australia. \\ * Corresponding author: leilacarmonabarnosi@gmail.com
}

\begin{abstract}
The Indo-Pacific aeolid nudibranch Moridilla brockii Bergh, 1888 comprises a species complex. Here we describe two morphs from the complex as new species. Using morphological comparisons, we show the new species to be closely related but distinct from each other and from M. brockii. Distributed across north-western Australia, M. fifo sp. nov. is known from Exmouth, Western Australia to the Wessel Islands, Northern Territory, whereas M. hermanita sp. nov. is known only from Madang, Papua New Guinea. Differences between the two species include colouration, the size of the receptaculum seminis and some distinction in the jaws. Unravelling the entire complex will take much wider geographic sampling, and will require recollection from the type locality of $M$. brockii. This group is yet another example of a purportedly widespread aeolid species comprising a complex of species.
\end{abstract}

KEYWORDS: nudibranchia, morphology, cryptic species complex

urn:Isid:zoobank.org:pub:2D0B250B-74DC-4E55-814B-0B2FB304200A

\section{INTRODUCTION}

As our understanding of the ocean's biodiversity improves, so does the recognition of previously undetected cryptic diversity. In many cases, this is assisted by enhanced technology or additional sources of data such as DNA sequencing. However in many cases, it is simply by having broader geographic taxon sampling. This is certainly true for taxa thought to be widespread, but later shown to consist of a complex of species. Recent investigations into presumed widespread aeolid species has resulted in the recognition of multiple species (e.g. Carmona et al. 2014a, b, c, Wilson \& Burghardt 2015, Kienberger et al. 2016).

This study focuses on the monotypic genus Moridilla Bergh, 1888, first described from Indonesia, and subsequently reported throughout the Indo-Pacific (e.g. Gosliner et al. 2015). The original description had only a few notes on live colouration from the collector Brock, and was based on a single individual (Bergh, 1888). A subsequent redescription was based on a large number of animals collected from the Gulf of Mannar,
India, which reported some important differences, such as the position of the anus, the papillate patterning of the rhinophores and general body colouration (Rao, 1965), and thus, may not represent the original species. One of the unique features of this genus is that the morphology of most of the dorsal cerata close to the midline of the body are different to the rest. They are substantially elongated, held in coiled position, and are differently coloured to the others. When a threat is sensed by the animal, these are extended full length (presumably to make the animal look larger) and are waved about vigorously.

In north-western and northern Australia, there exists a distinctive colour morph of $M$. 'brockii', not found elsewhere. Here we describe its morphology, derive mitochondrial DNA sequence data and elevate it to a species-level taxon. We also describe a new species from Papua New Guinea, which is the sister species to the northern Australian species according to molecular data (unpubl. obs). Unravelling the phylogeny and systematics of the entire complex is an ongoing endeavour. 


\section{METHODS}

The material utilised in the present study is housed in the Western Australian Museum, Perth (WAM), Museum and Art Gallery of the Northern Territory, Darwin (MAGNT), and the California Academy of Sciences, San Francisco (CAS) (see Table 1). Specimens were either preserved directly in ethanol, or relaxed and fixed in $10 \%$ formalin. The buccal masses were removed from the animals and placed in a solution of sodium hydroxide. After about 24 hours of digestion, the connective membranes were removed with fine needles from the remainder of the buccal apparatus and jaw and radula isolated. The jaws and radula were cleaned in multiple baths of molecular grade water and placed on SEM stubs with carbon tape. Once dried, the specimens were imaged at variable voltage uncoated in a Hitachi TM3030Plus, Tabletop Scanning Electron Microscope (SEM). Female genitalia were removed under a Leica M80 dissecting microscope, and illustrated with the aid of a camera lucida.

DNA was extracted from tissue samples using a DNeasy blood \& tissue kit (Qiagen) according to manufacturer's instructions. 1-2 ul of extraction were used in subsequent $25 \mathrm{ul} \mathrm{PCR}$ reactions using $0.2 \mathrm{ul}$ taq. Partial Cytochrome c Oxidase subunit I (COI) was amplified using the universal primers $\mathrm{LCO} / \mathrm{HCO}$ (Folmer et al. 1994), using standard PCR conditions, annealing primers at $48^{\circ} \mathrm{C}$. Sequencing was outsourced to the Australian Genome Research Facility (AGRF) and the bi-directional reads were assembled and edited using Geneious v9 (Kearse et al. 2012).

\section{SYSTEMATICS}

\section{Heterobranchia Burmeister, 1837}

Nudibranchia Cuvier, 1817

Superfamily Aeolidioidea Gray, 1827

Family Facelinidae Bergh, 1889

\section{Genus Moridilla Bergh, 1888}

Moridilla Bergh, 1888: 680.

Moridella Rao, 1965 (incorrect spelling).

Morildilla internet useage (incorrect spelling).

\section{TYPE SPECIES}

Moridilla brockii Bergh, 1888 by original designation.

\section{REMARKS}

Bergh (1888) described this monospecific genus based on a single specimen collected from Edam, which is an island from the South Thousand Islands Archipelago (Kepulauan Seribu) off Jakarta, Indonesia. The island itself is now known as Damar Besar/Damar Tengah (5 57'26"S, 106 $\left.50^{\circ} 40^{\prime \prime} \mathrm{E}\right)$. According to Bergh (1888) this genus is characterised by having 'Corpus gracilius, elongatum, subcompressum; rhinophoria quasi moriformia; tentacula sat elongata. Papillae (dorsales) vix caducae, elongate; seriebus obliquis dispositae, antice areis confertis. Podarium sat angustum, antice

TABLE 1 Material used in this study. Types in bold.

\begin{tabular}{|c|c|c|c|c|c|c|c|}
\hline Accession & Species & Location & Depth (m) & SEM & Dissection & Type status & Live photo \\
\hline WAM S12621 & fifo & Dampier Archipelago, WA & 7 & & & & no \\
\hline WAM S44511 & fifo & Kimberley, WA & 11 & YES & YES & Paratype & yes \\
\hline WAM S58696 & fifo & Kimberley, WA & 20 & & & & no \\
\hline WAM S78642 & fifo & Dampier Archipelago, WA & 8 & & & & yes \\
\hline WAM S85199 & fifo & Kimberley, WA & 13 & & & & no \\
\hline WAM S85204 & fifo & Kimberley, WA & 12 & YES & YES & Paratype & no \\
\hline WAM S92140 & fifo & Exmouth, WA & 7 & & & & yes \\
\hline WAM S92144 & fifo & Exmouth, WA & 7 & & & & yes \\
\hline WAM S92164 & fifo & Exmouth, WA & 7 & & & & yes \\
\hline WAM S96060 & fifo & Montebello Islands, WA & 16 & YES & YES & Paratype & yes \\
\hline WAM S96061 & fifo & Montebello Islands, WA & 16 & YES & YES & Holotype & yes \\
\hline NTM P.58246 & fifo & Montebello Islands, WA & 8 & & & Paratype & yes \\
\hline WAM S98700 & fifo & Kimberley, WA & 15 & & & & yes \\
\hline WAM S98735 & fifo & Kimberley, WA & 13 & & & & yes \\
\hline WAM S99735 & fifo & Kimberley, WA & 27 & & & & no \\
\hline WAM S110014 & fifo & Dampier Archipelago, WA & 6 & & & & yes \\
\hline WAM S110068 & fifo & Dampier Archipelago, WA & 10 & & & & yes \\
\hline CASIZ 190756-A & hermanita & Madang, PNG & 5 & YES & YES & Holotype & yes \\
\hline CASIZ 190756-B & hermanita & Madang, PNG & 5 & & & Paratype & no \\
\hline
\end{tabular}




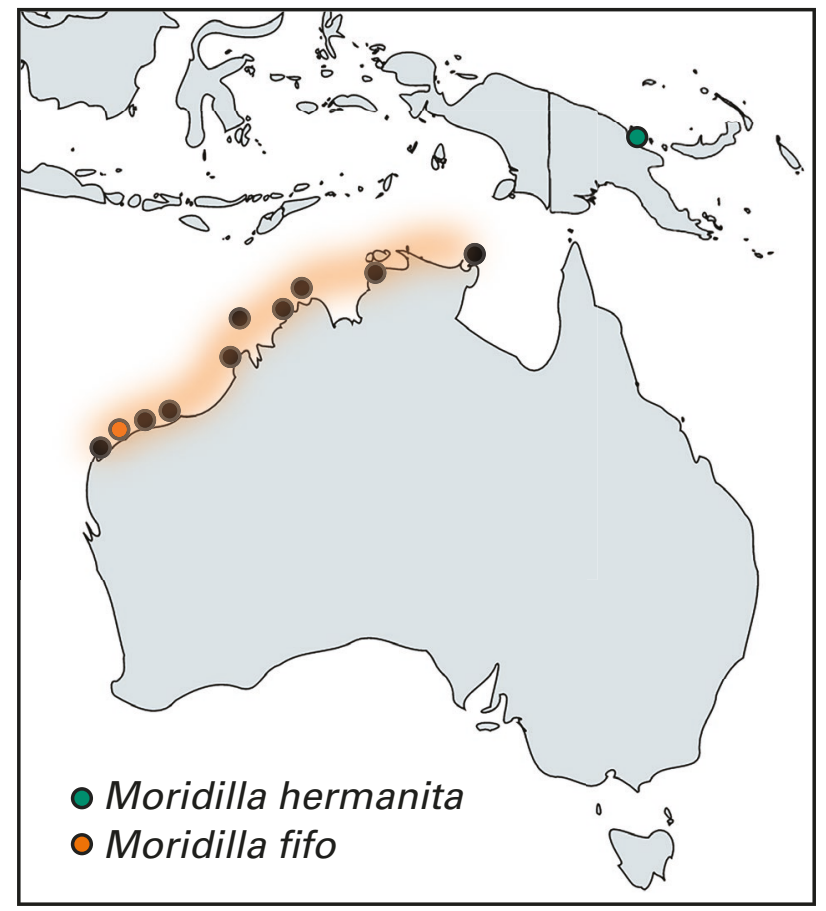

FIGURE 1 Distribution map of Moridilla fifo sp. nov. and M. hermanita sp. nov.. Coloured dots indicate type localities, black dots represent additional selected records.

angulis tentaculatim productis. Mandibule non elongatae; processus masticatorius mandibulae nonnihil curvatus, serie denticulorum grossiorum singula. Dentes linguae uniseriate, fere ut in Facelinis-Penis inermis'. Rao (1965) reviewed the genus and the type species (under the incorrect name Moridella brockii) with material from the Gulf of Mannar. The author found some differences in colouration, the position of the anus, and the rhinophorial papillae between Bergh's specimens and those studied by him. Some years later, Edmunds (1970) suggested that Moridilla and Palisa Edmunds, 1964 were very similar to Noumeaella Risbec, 1937, and needed a revision. However preliminary recent work has indicated that at least Moridilla is separated from Noumeaella (Carmona et al. 2015).

\section{Moridilla fifo sp. nov.}

Figures 1-4

urn:Isid:zoobank.org:act:ABE605B8-713D-4323-9BF9710025D70D0F

Moridilla sp 1.: Gosliner et al. 2015: 378.

Moridilla sp.: Debelius 1998: 309; Gosliner et al. 2008: 393.

Moridilla brockii Coleman 2008: p. 271 (middle left); Coleman 2001: 111 (lower middle); Coleman et al. 2015: 219 (lower right).

\section{MATERIAL EXAMINED}

\section{Holotype}

Australia: Western Australia: Montebello Islands, N. of Pansy Island, $20^{\circ} 35548 \mathrm{~S}, 115^{\circ} 55082 \mathrm{E}, 15$ April 2015, SCUBA, 16 m, coll: Kara Layton (WAMS 96061), dissected. COI accession MH673283.

\section{Paratypes}

Australia: Western Australia: From type locality, (WAMS 96060), dissected. Montebello Islands, E of Trimouille, west channel, $20^{\circ} 38412^{\prime} \mathrm{S}, 115^{\circ} 53884^{\prime} \mathrm{E}, 18$ April 2015, SCUBA, $8 \mathrm{~m}$, coll: Clay Bryce (WAMS 96363). Kimberley; Coulomb Point, $17.420167^{\circ} \mathrm{S}$,

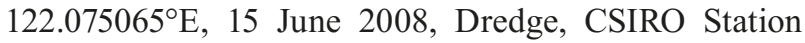
2037(a), 11 m, coll: John Keesing (WAMS 44511), dissected. Kimberley, Patricia Island, $14^{\circ} 15^{\prime} 10.729^{\prime \prime S}$, 125'18'15.941"E, 22 Oct 2012, SCUBA, 12 m, coll: Clay Bryce (WAMS 85204), dissected.

\section{Other material examined}

Australia: Western Australia: Kimberley, Eclipse Islands, $13^{\circ} 31^{\prime} 17.695^{\prime} \mathrm{S}, 125^{\circ} 54^{\prime} 22.072^{\prime} \mathrm{E}$, Epibenthic Sled, Station ECL40/WA097, 27 m, coll: Oliver Gomez and Jenelle Ritchie (WAMS 99735). Kimberley, Bonaparte Archipelago, Condillac Island, $1^{\circ} 06^{\prime} 37.657^{\prime} \mathrm{S}$, 125³3'34.096"E, 21 Oct 2012, SCUBA, 13 m, coll: Clay Bryce (WAMS 85199). Kimberley, Bonaparte Archipelago, North Maret Island, $14.42968^{\circ} \mathrm{S}$, $124.97859^{\circ}$ E, 17 Sep 2016, SCUBA, Station 185/K16, 12 m, coll: Lisa Kirkendale (WAMS 98735). Kimberley, Bonaparte Archipelago, Robroy reefs, $14.42952^{\circ} \mathrm{S}$,

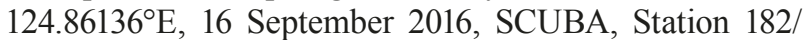
K16, 15 m coll: Lisa Kirkendale and Nerida Wilson (WAMS 98700). Kimberley, Adele Island, 15²6'40.56"S, $123^{\circ} 10^{\prime} 14.877^{\prime \prime E}, 15$ October 2009, SCUBA, Station 06/ K09, 20 m, coll: Clay Bryce, Corey Whisson (WAMS 58696). Dampier Archipelago, West Lewis Island, 20³6.249'S, $116^{\circ} 35.710^{\prime} E$, 27 Jul 2000, SCUBA, Station DA4/00/06, 7 m, coll: Clay Bryce (WAMS 12621). Dampier Archipelago, West Lewis Island, $20.59016^{\circ} \mathrm{S}$, 116.60554 E, 29 Mar 2017, SCUBA, Station 23/D17, 10 m, coll: Lisa Kirkendale, Nerida Wilson, \& Michelle Condy (WAMS 110014). Dampier Archipelago, West Lewis Island, $20.60455^{\circ} \mathrm{S}, 116.59530^{\circ} \mathrm{E}, 29 \mathrm{Mar} 2017$, SCUBA, Station 25/D17, 2-6 m, coll: Zoe Richards, Andrew Hosie, Ana Hara (WAMS 110068). Dampier Archipelago, Flying Foam Passage, $20.46743^{\circ} \mathrm{S}, 116.82782^{\circ} \mathrm{E}, 23$ March 2017, SCUBA, Station 4/D17, 8 m, coll: Lisa Kirkendale, Nerida Wilson \& Michelle Condy (WAMS 78642). Exmouth Gulf, Bundegi Reefs, $21.87053^{\circ} \mathrm{S}, 114.15874^{\circ} \mathrm{E}, 1$ June 2016, Station 3/EM16, 7 m, coll: Clay Bryce \& Nerida Wilson (WAMS 92140, 92144, 92164).

\section{Additional geographic records (not examined):}

Bynoe Harbour, NTM P.23589; Darwin Harbour, NTM P.1310, NTM P.18072, NTM P.54331; Wessel Islands (near Nhulunbuy, previous name Gove) NTM P.32121.

\section{DISTRIBUTION}

Moridilla fifo sp. nov. is currently known from a southern point at Exmouth, WA, to a northern record at the Wessel Islands, Northern Territory (Figure 1). 


\section{DESCRIPTION}

Colour: The general body colour, including the foot corners, is translucent white to pale orange. The oral tentacles, rhinophores, and tail are bright orange, almost red. The olive-green digestive gland is often visible through the ceratal surface. In some specimens the ceratal surface are light blue, with a white subapical ring. Some other individuals have completely white or orange-red pigmented cerata. Most specimens have bright orange, almost red, cnidosacs. The distal tips of the ceratal surface of the large, coiled innermost cerata are always bright orange-red. The cnidosacs are not visible in these coiled cerata. The tail tip is orange on the midline.
External morphology: The body is elongate and moderately broad, narrowing to the posterior end of the foot (Figure 2). The anterior foot corners are tentaculiform and short. The rhinophores are long, with elongate papillae on the posterior side. The oral tentacles are three times the length of the rhinophores. Cerata are spindle-shaped, long, and abundant. They are curved inwards towards the dorsal midline. They are arranged in up to five groups, one precardiac and four postcardiac, constituted by oblique rows. Each group have at least one long and coiled cera. This cera is placed in the upper part of the oblique row, close to the midline of the individual. Each row contains between 2 and 10
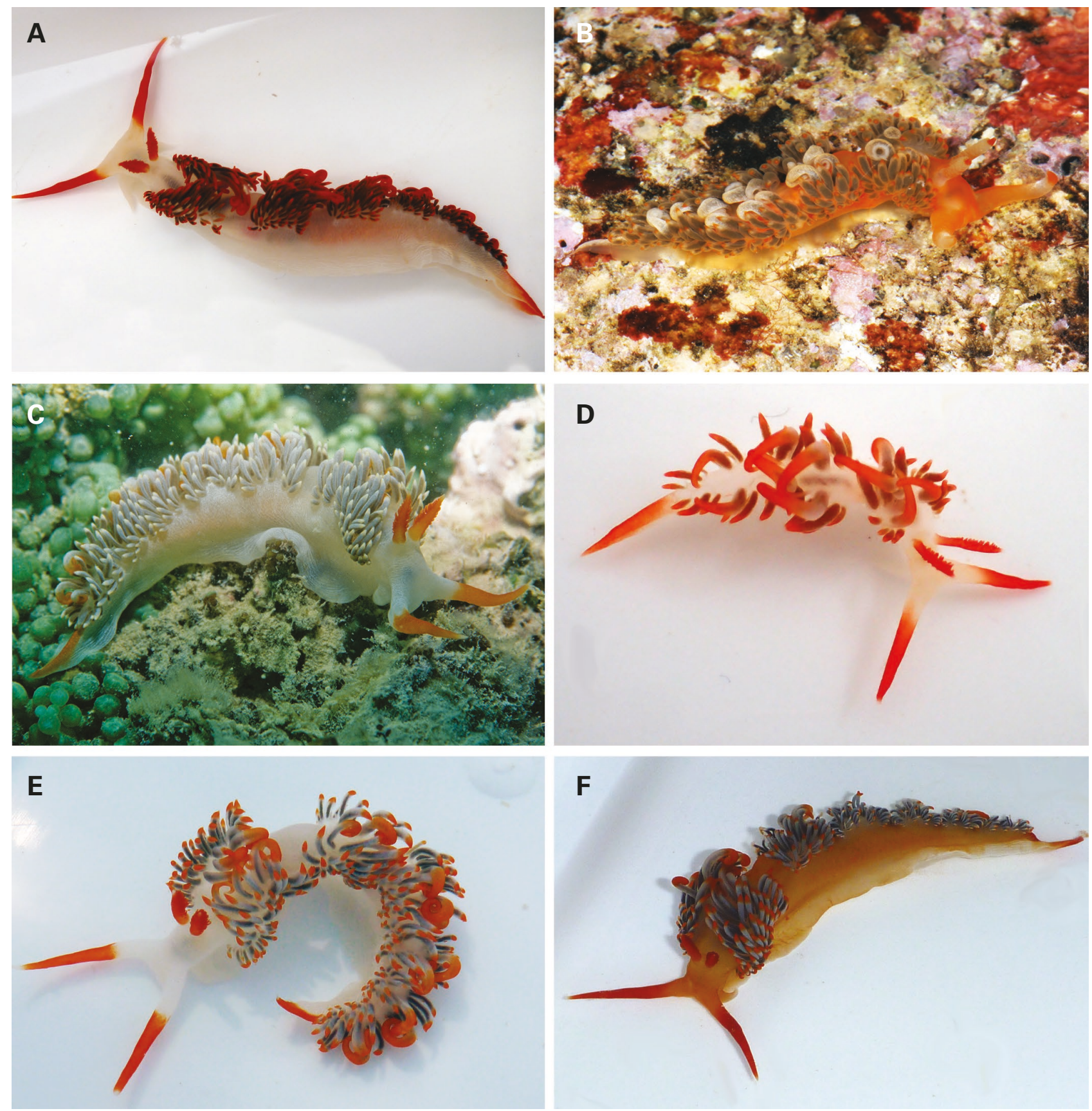

FIGURE 2 Live images of: A) Moridilla fifo sp. nov. holotype WAMS96061; B) M. hermanita sp. nov. holotype CASIZ190756A; C) M. fifo sp. nov. WAMS63396; D) M. fifo sp. nov. juvenile WAMS110014; E) M. fifo sp. nov. WAMS98735; F) M. fifo sp. nov. WAMS92144. 

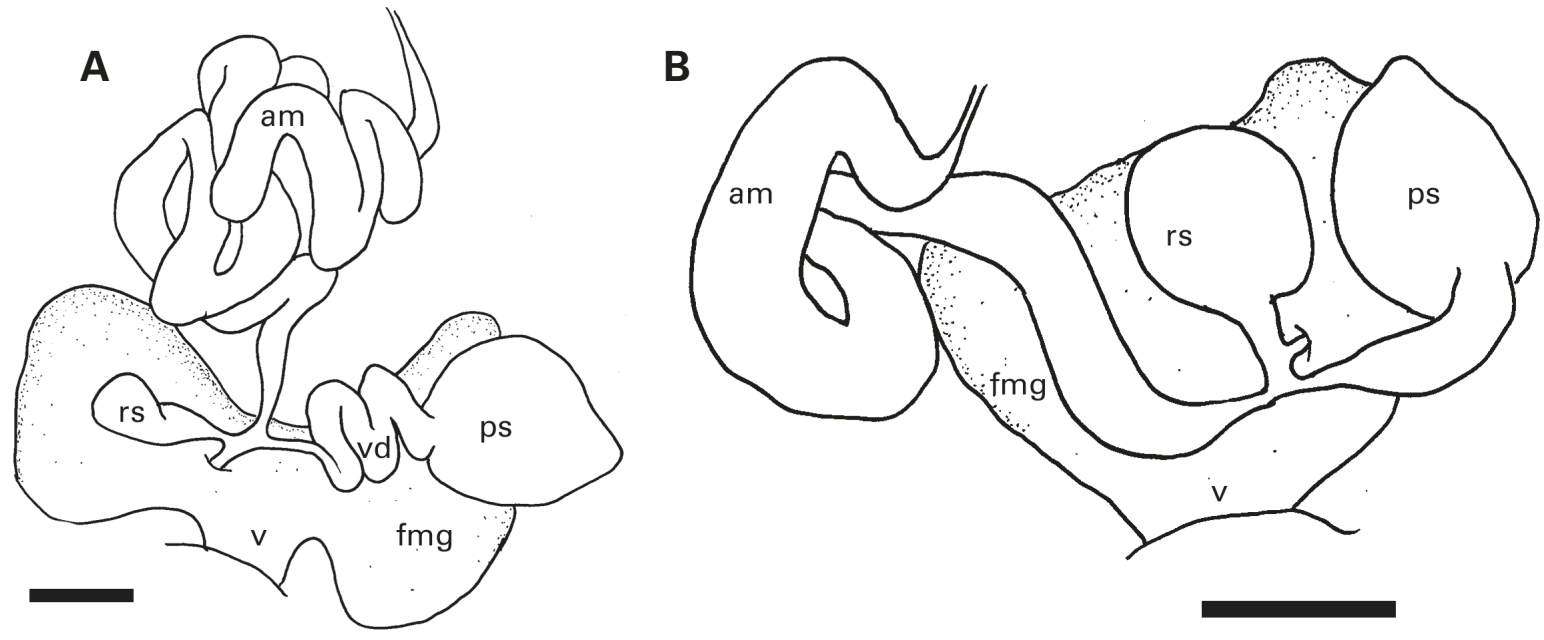

FIGURE 3 Reproductive system of: A) Moridilla fifo sp. nov. WAMS96060, scale bar represents $1 \mathrm{~mm}$; B) M. hermanita sp. nov. CASIZ190756A, scale bar $=0.5 \mathrm{~mm}$.

cerata. The anus is below the third group of cerata. The genital aperture is beneath the first right group of cerata. Internal morphology: The radular formula are: $19 \times 0.1 .0$ (WAMS85204), $20 \times 0.1 .0$ (WAMS44511), $24 \times 0.1 .0$ (WAMS96060), and 25 x 0.1.0 (WAMS96061) (latter two, paratype and holotype, shown in Figure 4E, H). The radular teeth have well developed and triangular central cusp, with 3 or 4 smooth denticles on each side (Figure 4D, G). The jaws are translucent brown, large, and broad (Figure 4F, I). The masticatory border of the jaws bears up to 18 comb-like denticles.

The reproductive system is diaulic (Figure 3). The hermaphroditic duct widens into large ampulla, which narrows again before dividing into the oviduct and vas deferens. The short vas deferens continues towards a well differentiated prostate, and finishes in the penial sac. The oviduct is short and connects to a small receptaculum seminis. The remaining portion of the oviduct separates from the base of the receptaculum and enters the female gland. The vagina opens ventrally relative to the penis.

\section{REMARKS}

Moridilla fifo sp. nov. has only been recorded from Exmouth, WA, north through the Pilbara and Kimberley, along the top of Australia as far east as Nhulunbuy, Northern Territory. It is known from the intertidal to $27 \mathrm{~m}$ depth, concurrent with observations made by SCUBA divers. The type species, $M$. brockii needs further clarification, as no specimens from the type locality have been examined in recent studies. The original description reported live colouration of the cerata as 'blackish' with a light tip and a milky body colour (Bergh, 1888). Given that we now understand that there is a large complex of undescribed species associated with that name (unpub. obs), the application of the name M. brockii to Rao's specimens cannot be justified. The colour morph here described as M. fifo sp. nov. has never been recorded away from the Australian coast, although other colour morphs of Moridilla have also been found overlapping with $M$. fifo sp. nov. in Australia. Therefore, the likelihood that $M$. fifo sp. nov. could be a synonym of $M$. brockii is extremely low. Accessing and sequencing samples from the type locality should be a priority for fixing the name.

\section{ETYMOLOGY}

The specific epithet refers to the method of employing a workforce (known as 'fly-in-fly-out', abbrev. FIFO, used as a noun in apposition) that is only temporarily located at a work site. This is very common for remote locations in the mining industry in the north-west of Australia where M. fifo sp. nov. is known. This employment mechanism is analogous to the method that many aeolids use, including Moridilla, to move a temporary workforce of undigested nematocysts from their cnidarian prey to the tips of their cerata to use for defense.

\section{Moridilla hermanita sp. nov.}

Figures 1-4

urn:Isid:zoobank.org:act:F73BA31F-BD92-453C-9D914E76A8BD73FC

\section{MATERIAL EXAMINED}

\section{Holotype}

Papua New Guinea: Madang Province: N Kranket

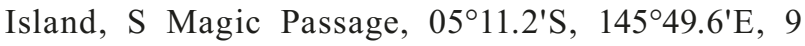
December 2012, SCUBA, Station PR215, $5 \mathrm{~m}$, coll. Terrence M. Gosliner (CASIZ 190756_A). COI accession MH673282.

\section{Paratype}

Papua New Guinea: Madang Province: From type locality, (CASIZ 190756 B). 


\section{DISTRIBUTION}

Moridilla hermanita sp. nov. is known only from a single location off Kranket Island, Madang, Papua New Guinea (Figure 1).

\section{DESCRIPTION}

Colour: The general body colour, including the foot corners and oral tentacles, is translucent orange. The rhinophores are pale, almost white with bright orange tips. The eyes are visible at the posterior base of the rhinophores. The distal third of the oral tentacles is covered by white pigments, with bright orange tips. The olive-green digestive gland is visible through the ceratal surface. The cerata have a white subapical ring and bright orange cnidosacs. White pigments cover the large, innermost coiled cerata. The cnidosacs are not visible in these coiled cerata. The tail tip is white on the midline.
External morphology: The body is elongate and moderately broad, narrowing to the posterior end of the foot. The anterior foot corners are tentaculiform and short. The rhinophores are long, completely covered by moderate papillae. The oral tentacles are twice the length of the rhinophores. Cerata are spindle-shaped, long, and abundant, but leaving a bare zone from behind the rhinophores to the tail. They are curved inwards towards dorsal mid line. They are arranged in up to five groups, one precardiac, four postcardiac, constituted by oblique rows. Each group has between 4 and 8 rows. Each group has at least one long and coiled cera. This cera is placed in the upper part of the oblique row, close to the midline of the individual. Each row contains between 2 and 8 cerata. The anus is below the third group of cerata. The genital aperture is beneath the first right group of cerata. Internal morphology: The radular formula is

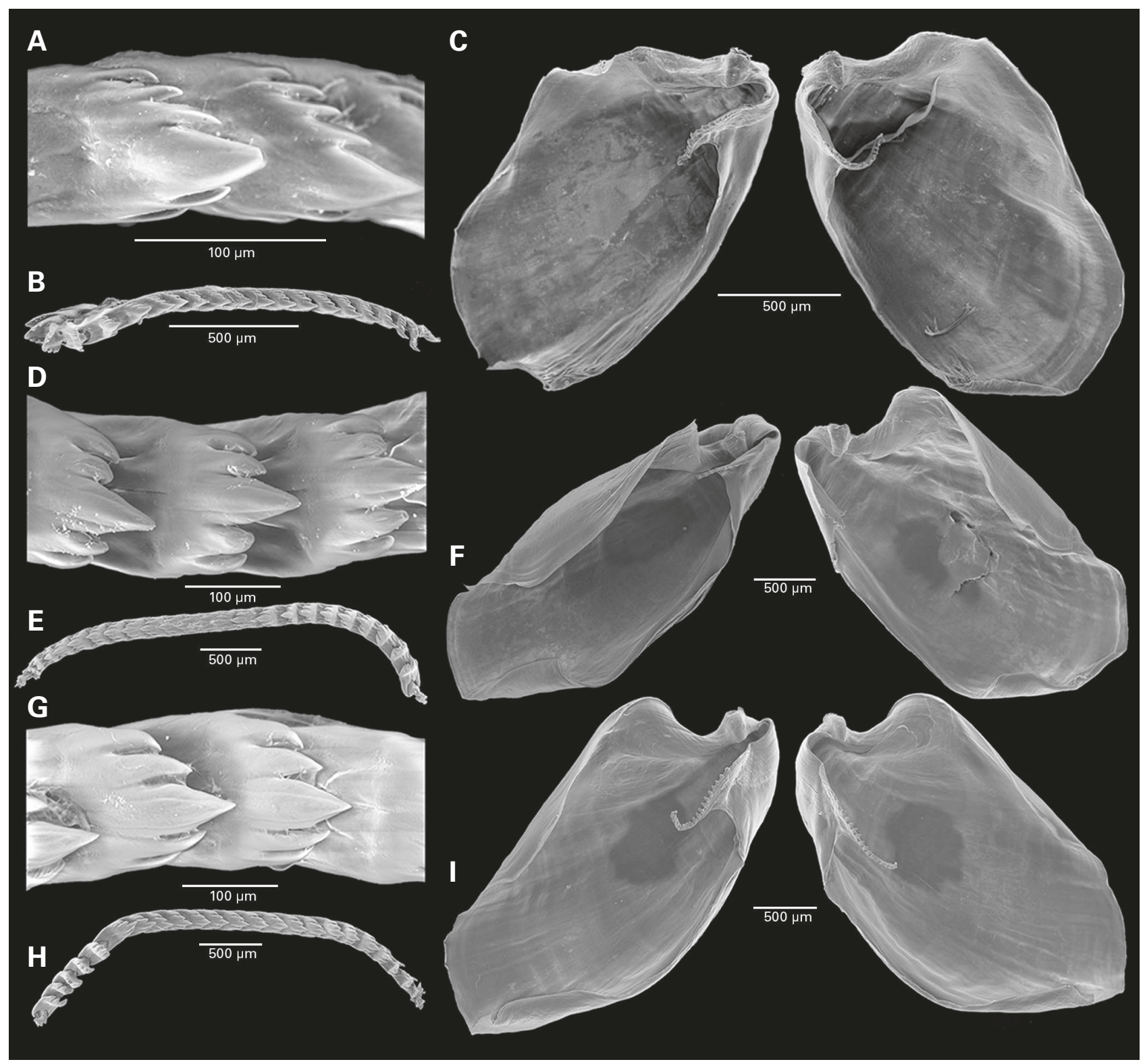
holotype of M. fifo sp. nov. WAMS96061; G-I) paratype of M. fifo sp. nov. WAMS96060. 
22 x 0.1.0 (CASIZ 190756_A, holotype, Figure 4B). The radular teeth have a well developed and triangular central cusp, with 3 or 4 denticles on each side (Figure 4A). The jaws are translucent brown, large, and broad (Figure 4C). The masticatory border of the jaws bears up to 11 comblike denticles.

The reproductive system is diaulic (Figure 3). The hermaphroditic duct widens into large ampulla, which narrows again before dividing into the oviduct and vas deferens. The short vas deferens continues towards a well differentiated prostate, and finishes in the penial sac. The oviduct is short and connects to a large, rounded receptaculum seminis. The remaining portion of the oviduct separates from the base of the receptaculum and enters the female gland. The vagina opens ventrally relative to the penis.

\section{REMARKS}

So far this species is known only from two specimens collected from Madang, Papua New Guinea. The external colouration is very different to that of its sister species, $M$. fifo sp. nov. In particular, the rhinophores in $M$. hermanita sp. nov. are pale with orange tips, but show the reverse colouring in $M$. fifo sp. nov., which has orange rhinophores with pale tips. Similarly, the oversized, curled, midline cerata are coloured white in $M$. hermanita sp. nov. but orange in $M$. fifo sp. nov.. Internally, the two also differ in the shape of the receptaculum seminis.

\section{ETYMOLOGY}

The specific epithet, 'little sister' in Spanish, honours the first author's younger sister, Ana Carmona Barnosi, and this species sister status with $M$. fifo sp. nov. (unpubl. obs).

\section{ACKNOWLEDGEMENTS}

We are deeply indebted to Ann Jones (ABC Radio National) and Amber Beavis (Office of the Prime Minister for Science) for assistance in opening a competition to search for a name for the Western Australian Moridilla. We are equally thankful that Patrick Dwyer, NSW, came up with the unique winning entry. All entrants are thanked for their creative name suggestions. We are also grateful to Terry Gosliner and Elizabeth Kools (both CAS) for assisting with loans of material, and to Richard Willan (MAGNT) for museum records. Peter Middelfart carried out the SEM and helped solve the type locality for $M$. brockii, and Diana Prada, Michelle Condy and Alex Hickling assisted with sequencing (all WAM). Western Australian collections were made under permits granted by the Department of Parks and Wildlife (Reg. 17 SF010218, SF010710, 08-000214-1; Reg. 4 exemptions CE004584, CE005306) and the Department of Fisheries (1718-2009-53; 20852012; LATMS 14-731, exemption 2455; LATMS 16-76, exemption 2756; LATMS 14-731v2, exemption 2550). Woodside Energy supported the Woodside Collection project at the WA Museum in the Kimberley from 2009-2015, and the 12th International Marine Biological Workshop in Dampier 2000. For cultural advice and permissions to work on sea country, we would like to thank Wunambal Gaambera Aboriginal Corporation, WGAC Healthy Country manager Tom Vigilante and WGAC's Uunguu Rangers Leonie Cheinmora and Marlene Djanghara, as well as Stuart Field, Andrew Heyward, and the Western Australian Marine Science Institute's Seabed Biodiversity project. Some material also originated from the CSIRO-WAM Kimberley Hub work in 2008.

The molecular material from Papua New Guinea in this paper originates from the shore based expedition conducted by the Museum Naturelle de Histoire Naturelle (MNHN) in collaboration with the University of Papua New Guinea and Pro-Natura International (PNI) as part of the Our Planet Reviewed program, conducted during 2012, headed by Philippe Bouchet. Funders and sponsors include the Total Foundation, Prince Albert II of Monaco Foundation, Stavros Niarchos Foundation, and Richard Lounsbery Foundation. We especially thank Philippe Bouchet and Virginie Héros, Philippe Maestrati, Pierre Lozouet, Barbara Buge, Ellen Strong and Laurent Charles for their role in specimen processing during the expeditions. Specimens were collected under permit to the MNHN and imported to the United States under permit number 2012205848 from the U.S Fish and Wildlife Service.

This study was supported by a Gorgon Barrow Island Net Conservation Benefits grant to the Western Australian Museum administered by the Western Australian Department of Parks and Wildlife. Leila Carmona was funded by the Swedish Taxonomy Initiative grant dha 2015-7 4.3.

\section{REFERENCES}

Bergh, L.S.R. (1888). Beiträge zur Kenntniss der Aeolidiaden. IX. Verhandlungen der königlichkaiserlich ZoologischBotanischen Gesellschaft in Wien (Abhandlungen) 38: 673-706, pls 16-20.

Carmona, L., Pola, M., Gosliner, T.M. and Cervera, J.L. (2014a). The end of a long controversy: systematics of the genus Limenandra (Mollusca: Nudibranchia: Aeolidiidae). Helgoland Marine Research 68(1): 37-48.

Carmona, L., Bhave, V., Salunkhe, R., Pola, M., Gosliner, T.M. and Cervera, J.L. (2014b). Systematic review of Anteaeolidiella (Mollusca, Nudibranchia, Aeolidiidae) based on morphological and molecular data, with a description of three new species. Zoological Journal of the Linnean Society 171(1): 108-132.

Carmona, L., Lei, B.R., Pola, M., Gosliner, T.M., Valdés, Á. and Cervera, J.L. (2014c). Untangling the Spurilla neapolitana (Delle Chiaje, 1841) species complex: a review of the genus Spurilla Bergh, 1864 (Mollusca: Nudibranchia: Aeolidiidae). Zoological Journal of the Linnean Society 170(1): 132-154. 
Carmona, L., Pola, M., Gosliner, T.M. and Cervera, J.L. (2015). Burnaia Miller, 2001 (Gastropoda, Heterobranchia, Nudibranchia): a facelinid genus with an Aeolidiidae's outward appearance. Helgoland marine research 69(3): 285.

Coleman, N. (2001). 1001 Nudibranchs. Neville Colemans' Underwater Geographic, Springwood, Australia. 144 pp.

Coleman, N. (2008). Nudibranchs Encyclopedia. 1st Ed. Neville Colemans' Underwater Geographic, Springwood, Australia. 416 pp.

Coleman, N., Cobb, G. and Mullins, D. (2015). Nudibranchs Encyclopedia. 2nd Ed. Masalai Press, USA. 311 pp.

Debelius, H.(1998). Nudibranchs and Sea Snails, Indo-Pacific Field Guide. IKAN- Unterwasserarchiv, Frankfurt. $321 \mathrm{pp}$.

Edmunds, M. (1970). Opisthobranchiate Mollusca from Tanzania: II. Eolidacea (Cuthonidae, Piseinotecidae and Facelinidae). Journal of Molluscan Studies 39(1): 15-58.

Folmer O., Black, M., Hoeh, W., Lutz, R. and Vrijenhoek, R. (1994). DNA primers for amplification of mitochondrial cytochrome c oxidase subunit I from diverse metazoan invertebrates. Molecular Marine Biology and Biotechnology 3: 294-299.

Gosliner, T.M., Behrens, D.W. and Valdes, A. (2008). IndoPacific Nudibranchs and Sea Slugs. Sea Challengers, Washington. $425 \mathrm{pp}$.
Gosliner, T.M., Valdes, A. and Behrens, D.W. (2015). Nudibranch \& Sea Slug identification, Indo-Pacific. New World Publications, Inc. Jacksonville, Florida. pp. 408.

Kearse, M., Moir, R., Wilson, A., Stones-Havas, S., Cheung, M., Sturrock, S., Buxton, S., Cooper, A., Markowitz, S., Duran, C. and Thierer, T. (2012). Geneious Basic: an integrated and extendable desktop software platform for the organization and analysis of sequence data. Bioinformatics 28(12): 1647-1649.

Kienberger, K., Carmona, L., Pola, M., Padula, V., Gosliner, T.M. and Cervera, J.L. (2016). Aeolidia papillosa (Linnaeus, 1761)(Mollusca: Heterobranchia: Nudibranchia), single species or a cryptic species complex? A morphological and molecular study. Zoological Journal of the Linnean Society 177(3): 481-506.

Rao, K.P. (1965). Moridella brockii Bergh 1888, redescribed with notes on anatomy and early development. Journal of the Marine Biological Association, India 7(1): 61-68.

Wilson, N.G. and Burghardt, I. (2015). Here be dragonsphylogeography of Pteraeolidia ianthina (Angas, 1864) reveals multiple species of photosynthetic nudibranchs (Aeolidina: Nudibranchia). Zoological Journal of the Linnean Society 175(1): 119-133.

MANUSCRIPT RECEIVED 3 MAY 2018; ACCEPTED 29 JUNE 2018. 